\title{
Industrial Energy Efficiency Towards Green Deal Transition. Case of Latvia.
}

\author{
Kristaps LOCMELIS ${ }^{1 *}$, Andra BLUMBERGA ${ }^{2}$, Uldis BARISS $^{3}$, Dagnija BLUMBERGA $^{4}$, \\ Lauma BALODE ${ }^{5}$ \\ ${ }^{1-5}$ Institute of Energy Systems and Environment, Riga Technical University, Azenes iela 12/1, Riga, Latvia
}

\begin{abstract}
Energy efficiency policy has been one of the European Union top priorities for decades and will continue to play a vital role in the next 10 years with the introduction of The Clean energy for all Europeans. Likewise, in Latvia energy efficiency has been given high priority; however, the energy efficiency targets for industry has lacked ambitions. This research focuses on evaluating the Latvian industrial energy efficiency policy using top-down approach and benchmarking energy intensity of Latvian industry to the average of the European Union's. Results confirm that on average Latvian industry consumes 2.6 times more energy to produce the same amount of value added compared to the average in the European Union; however, every saved energy unit in Latvia would save twice less $\mathrm{CO}_{2}$ emissions considering already largely decarbonized energy mix. In the spotlights of the Green Deal proposed by the European Commission, much higher contribution in terms of $\mathrm{CO}_{2}$ reduction and energy efficiency will be expected from the industry. Nevertheless, energy efficiency targets for Latvian industry should be sector-specific, separately addressing $\mathrm{CO}_{2}$ intensive sectors, and non-intensive $\mathrm{CO}_{2}$ sectors with low added value.
\end{abstract}

Keywords - Industrial $\mathrm{CO}_{2}$ intensity; industrial energy efficiency; industrial energy intensity; top-down analyses; the Green Deal

\section{INTRODUCTION}

Energy efficiency policy has been one of the top priorities in European Union (EU) for more than 25 years. Energy efficiency is considered to be one of the cost-effective ways to ensure energy security, reduce carbon emissions and ensure economic competitiveness. EU Directives impose increasing mandatory energy efficiency targets to the Member States, however the particular way to reach the energy efficiency targets is up to the Member States themselves [1]-[4]. Another key aspect of energy efficiency policy implementation is the increased focus on the industrial sector as it is one of the largest greenhouse gas (GHG) emitters in the EU, causing approximately $20 \%$ of all GHG emissions in the EU [5]. Article 8 of Energy Efficiency Directive (EED) imposes mandatory energy audits for large enterprises or implementation of an energy or environmental management system certified by an independent body according to the relevant European or International Standards [3].

The Clean energy for all Europeans [6] envisages even more ambitious energy efficiency targets and recognizes essential importance of energy efficiency improvements to the environment, public health, reduction of GHG emissions and energy security by reducing dependence on energy imports from outside the EU. Even more so, it will cut energy costs for households and companies, help to reduce energy poverty, and lead to an increased

* Corresponding author.

E-mail address: kristaps.locmelis@gmail.com 
competitiveness, create more jobs and increase economic activity throughout the economy [4]. The former EU Energy Commissioner Mr. Arias Cañete admits that EU's energy price disparities with global competitors are a major cause for concern for the competitiveness of Europe's energy intensive industries, and European Commission offers the energy efficiency policy, which is one of the most crucial cornerstones in Clean energy for all Europeans proposal, as the tool to reduce the energy intensity of industrial activities [7].

There is an industrial EU state aid policy [8] that addresses the negative impact of energy prices on energy-intensive industries that are exposed to international competition by allowing energy taxation exemptions. However, the previous study [9] has shown that in certain circumstances the policy might discourage the energy-intensive companies to implement energy efficiency, which is contradictory to the Clean energy for all Europeans policy objectives.

On December 11, 2019 the newly established European Commission came up with even more ambitious climate goals by publishing The European Green Deal, aiming at the EU GHG neutrality by 2050 [5]. Fig. 1 illustrates elements of the Green Deal.

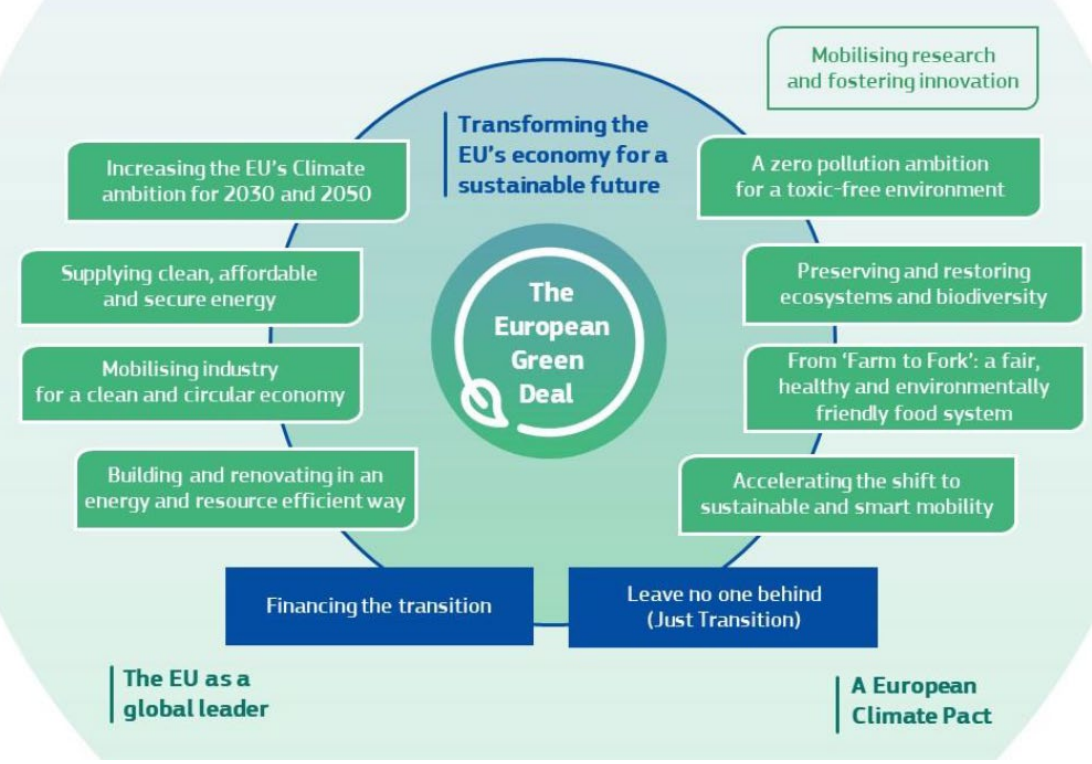

Fig. 1. The European Green Deal [5].

It is evident that achieving a climate neutral economy without full engagement of industry is not possible. The Green Deal recognizes that for industry it takes 25 years to transform all the value chains, and actions should be taken in coming 5 years to be decarbonized by 2050 . The Green Deal highlights the importance of decarbonisation of energy-intensive industries, such as steel, chemicals and cement, which is very topical for Latvia in particular with respect to cement industry. While there is existing well-established policy tools for industrial decarbonisation such as EU Emissions Trading System [10], it is most likely that climate neutrality policy in the EU could lead to competitiveness problems in certain energy-intensive industry sectors, especially where remarkable differences in climate ambition levels worldwide persist. However, the proposed solution does not provide for energy taxation exemptions, but rather a carbon border adjustment mechanism, to reduce carbon leakage risks [5]. Which means that energy efficiency policies would play a much more important 
role in energy-intensive industries and could be one of, if not the only one, sustainable solution for global competitiveness.

The aim of the study was to assess the Latvian energy efficiency policy objectives for industry by plotting the trajectory of policy targeted industrial energy intensity and its impact on $\mathrm{CO}_{2}$ emissions, taking into account country specific industrial $\mathrm{CO}_{2}$ intensity, as well as evaluate the level of energy efficiency ambitions in the context of the Green Deal and full decarbonisation of economy until 2050. In this study authors also assessed historical energy intensity of the three most dominant industrial sectors in Latvia and compared them with peers from other EU countries.

\section{Latvian National Energy Efficiency Plans for Industry}

Considering the different ambition levels of energy efficiency targets imposed by different EU directives, the Latvian energy efficiency plans have changed over time. However, it is noticeable that the achievable energy efficiency savings have increased with each reporting period, which confirms the growing importance of the policy.

\subsection{First energy efficiency reporting period 2008-2016}

The First energy efficiency action plan envisaged $3483 \mathrm{GWh}$ of cumulative energy efficiency savings indicative target for year 2016 [11]. The cumulative target was not changed in the Second energy efficiency action plan [12]. Energy efficiency action plans foresaw to achieve $170 \mathrm{GWh}$ of cumulative energy efficiency savings until the end of 2016 in industry and agricultural sectors combined (see Table 1), using such policy instruments as financial grants for reducing GHG emissions in industrial buildings, implementation of industrial energy audits and energy management systems.

Table 1. Estimated Cumulative Energy Savings Targets by Sector, GWh [12]

\begin{tabular}{llllllllll}
\hline & 2008 & 2009 & 2010 & 2011 & 2012 & 2013 & 2014 & 2015 & 2016 \\
\hline Households & 3 & 15 & 52 & 360 & 900 & 1471 & 1921 & 2311 & 2701 \\
Transport & 0 & 1 & 4 & 26 & 68 & 111 & 145 & 175 & 204 \\
Industry and Agriculture & 0 & 1 & 3 & 23 & 57 & 92 & 121 & 147 & 170 \\
Services & 1 & 2 & 8 & 54 & 136 & 222 & 290 & 349 & 408 \\
\hline Total & 4 & 19 & 67 & 463 & 1161 & 1896 & 2477 & 2982 & 3483 \\
\hline
\end{tabular}

The top-down method was used to assess the achievement of energy efficiency targets, as at that time there was a lack of comprehensive studies on the cost and economic returns of various available energy efficiency measures [12].

\subsection{Energy efficiency action plans 2014-2020}

In 2012, the National Development Plan of Latvia for 2014-2020 (NDP) was approved [13], where it was planned to reduce energy consumption for output of gross domestic product (GDP) by $25 \%$ compared to 2010 , reaching $280 \mathrm{~kg}$ of oil equivalent per EUR 1000 of GDP. The NDP also set goals for GHG emission intensity per LVL $1000^{\dagger}$ of GDP (see Table 2).

$\dagger 1 \mathrm{LVL}=1.42287$ EUR (source: Latvian Bank, 2012) 
TABle 2. GOALs of NDP ACTION Line ENERGY EFFICIENCY AND ENERGY PRODUCTION [13]

\begin{tabular}{|c|c|c|c|c|}
\hline & $\begin{array}{l}\text { Base value, } \\
\text { year }\end{array}$ & 2014 & 2017 & 2020 \\
\hline $\begin{array}{l}\text { Share of energy from renewable sources in } \\
\text { gross final energy consumption of at least } \\
40 \% \text { in } 2020\end{array}$ & 34.3 (2009) & 35 & 37 & 40 \\
\hline $\begin{array}{l}\text { Energy consumption for GDP, } \mathrm{kg} \text { of oil } \\
\text { equivalent per EUR } 1000 \text { of GDP }\end{array}$ & $372.9(2010)$ & 350 & 320 & 280 \\
\hline $\begin{array}{l}\text { Energy dependency - net energy imports / } \\
\text { gross domestic energy consumption plus } \\
\text { bunkering, } \%\end{array}$ & $41.6(2010)$ & 42.4 & 43.2 & 44.1 \\
\hline $\begin{array}{l}\text { GHG emission intensity, tonnes } \mathrm{CO}_{2} \text { per } \\
\text { LVL } 1000 \text { of GDP }\end{array}$ & 1.69 & 1.48 & 1.30 & 1.13 \\
\hline
\end{tabular}

Alongside the NDP, the status report on the progress towards the indicative national energy efficiency targets in 2014-2016 and National energy efficiency action plan until 2020 (NEEAP) [14], was published, which included information on mandatory energy efficiency savings until 2020. According to the NEEAP there were no specific energy efficiency targets as well as no specific energy efficiency promotion policy for industry sector in Latvia, leading to the conclusion that the industrial energy efficiency potential would be virtually untapped.

The NEEAP changed after enforcement of energy efficiency obligation on large enterprises and large electricity consumers by Energy Efficiency Law, which requires large enterprises and large consumers to perform a mandatory energy audit or to introduce and maintain a certified energy management system, or supplementary energy management to environmental management system [15]. The legal aspects of Energy Efficiency Law requirements are analysed by authors in previous publication [16]. According to the 'Alternative measure plan of Latvian energy efficiency policy on achieving energy efficiency targets for the period 2014-2020' [17], planned cumulative energy efficiency savings from energy efficiency obligation on large enterprises and large electricity consumers would reach $807.6 \mathrm{GWh}$ or $8 \%$ of all achievable cumulative energy efficiency savings until 2020.

The disproportionality of targeted cumulative energy efficiency savings from energy audits and energy management systems imposed on large electricity consumers and large enterprises, which largely represents industry and commercial sectors, and energy consumption by sectors is visualized in Fig. 2. Industry represented $23 \%$ of Latvian final energy consumption in 2015 (see Fig. 2a). Considering that consumption of transport sector was removed from energy efficiency target calculation, the share of industry in energy mix (without transport sector) is even higher and represents $33 \%$ (see Fig. 2b). Targeted energy efficiency potential from energy audits and energy management systems was modest $8 \%$ (see Fig. 2c). 


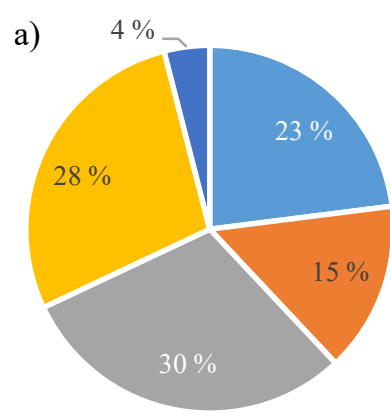

- Industry

- Public and commercial

sector

- Transport

" Households

- Agriculture, fishery and forestry b)

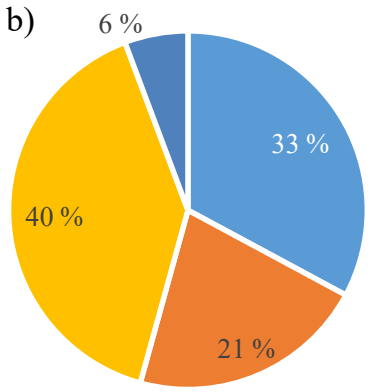

- Industry

- Public and commercial sector

Households

- Agriculture, fishery and forestry c)

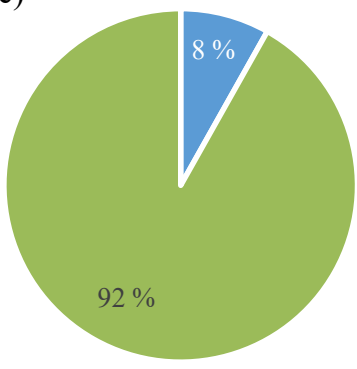

- Energy audits \& energy management system

- Other measures

Fig. 2. Energy consumption split in Latvia: a) all sectors (2015) and b) without transport sector (2015); c) cumulative energy savings (2020) target breakdown (created by the authors and based on [17]).

\subsection{Energy efficiency targets by 2030 and in the light of the Green Deal}

Latvian national binding energy efficiency targets for 2030 are set in National energy and climate plan (NECP) [18] and are calculated according to the requirements of EED and its amendments. According to the NECP, cumulative final energy efficiency savings in the period 2021-2030 should exceed 73.7 PJ or 20.5 TWh (for comparison it was 9.9 TWh for 2014-2020).

The largest contribution (approximately $44 \%$ ) is expected to come from energy savings in industry (see Fig. 3a), from which approximately $80 \%$ of savings should be achieved in industrial thermal processes and only $20 \%$ in industrial electricity savings (see Fig. 3b). The planned measures include the implementation of the already defined involvement of large companies in both the voluntary agreement system and the energy audit. In addition, greater involvement of companies in the implementation of energy efficiency measures through energy efficiency obligation scheme (EEOS) is envisaged.

The Green Deal proposal cardinally would change the industrial landscape of the EU. The European Commission's calculations forecast that current policies including the ones in Clean energy for all Europeans will only reduce GHG emissions by $60 \%$ by 2050 [5], and by summer 2020 the European Commission will come out with new policy proposals, most likely including the energy efficiency policy amendments, to implement more ambitious climate actions. 
a)

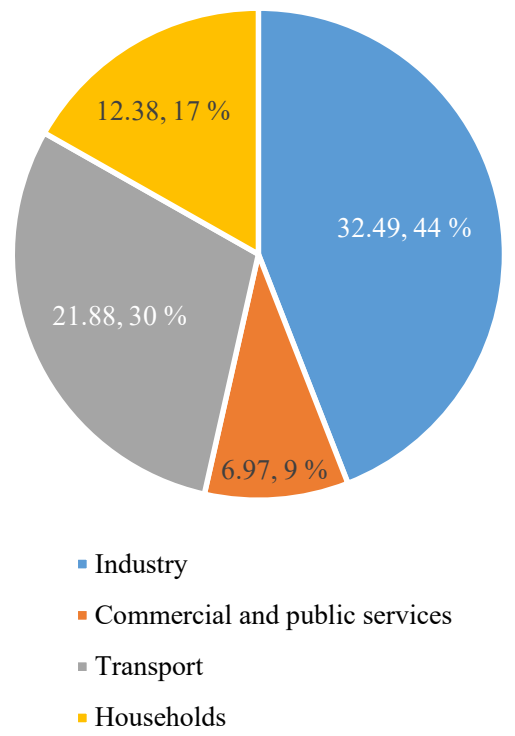

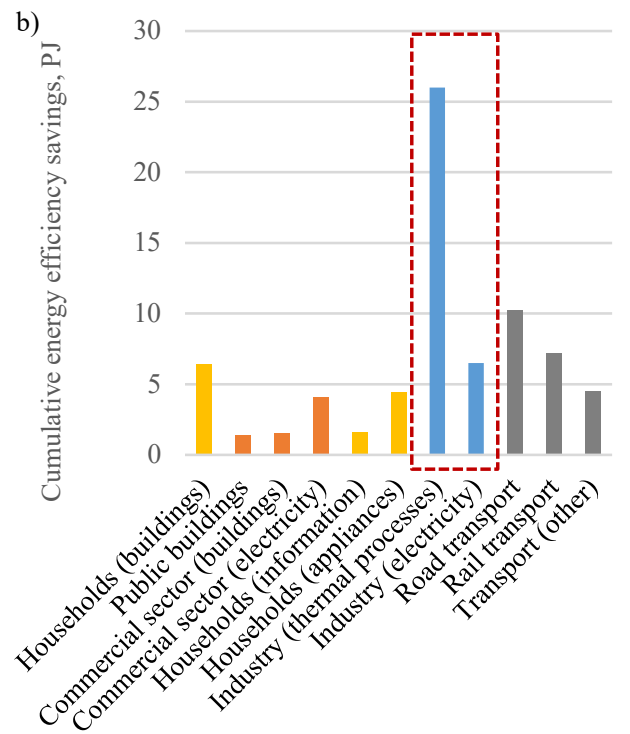

Fig. 3. Cumulative energy efficiency savings (2021-2030); a) breakdown by sectors, PJ and \%; b) breakdown by sectors and activities, PJ [18].

\section{Literature REVIEW}

Knoop and Lechtenbohmer (2017) [19] point out that energy efficiency improvement differs from simple energy savings by the fact that the energy efficiency improvement is measured for the same volume or value of output (or per unit of output). Consequently, the energy efficiency assessment takes into account whether the company has increased or decreased its production. However, there is a so-called energy efficiency paradox when some cost-effective energy efficient technologies are not being implemented or are being implemented very slowly [20]. This creates an energy efficiency gap, which describes the difference between current energy consumption levels and optimal energy consumption levels now or in the future [20].

The technical energy efficiency potential indicates the maximum theoretical reduction in energy consumption that can be achieved through the introduction of energy efficiency measures, provided that non-engineering barriers, including economic and regulatory barriers, behavioural and regulatory barriers, are fully resolved and lower transaction costs and faster technology diffusion are promoted. [19], [21].

The economic potential indicates which part of the technically feasible energy efficiency measures could be implemented in a cost-effective way, where cost effectiveness is defined as compared to the costs of alternative measures on the supply side [21]. Both the technical and economic potential for energy efficiency are most often perceived as theoretically achievable, provided that measures are implemented immediately, that is, delays affecting policy and program implementation, market barriers and the cost of energy efficiency promotion programs are not considered [21].

Achievable (or maximum attainable) potential refers to the energy consumption that can be reduced by implementing energy efficiency measures through the most aggressive policy mechanisms. This assessment of the potential considers the fact that not all will be persuaded 
to implement energy efficiency measures, as well as additional costs not directly related to energy efficiency measures and delay in reaching the potential [21].

The program potential represents the expected reduction in energy consumption due to the measures implemented within the framework of a specific energy efficiency promotion program. This potential takes into account the funding available within a given program and the design of the program (see Fig. 4). This potential can be identified for a single program, for a multi-program package, as well as to analyse the impact of different levels of funding on the programme's deliverables [21].

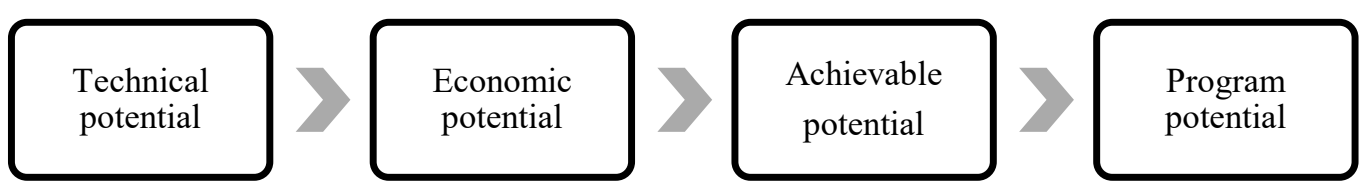

Fig. 4. Types of energy efficiency potential [21].

Knoop and Lechtenbohmer (2017) concluded that there is significant energy efficiency potential in EU Member States. This potential could range from 10 to $28 \%$ savings in 2030 compared to the baseline scenario if low intensity policy intervention is used [19].

There are two major methods of evaluating energy efficiency policy - on an industry level, by gathering statistics on industry consumption, structural and economic indicators or top-down method, which was largely developed in the eighties by Boyd et al. (1987) [22], Jenne (1983) [23] and Howarth (1991) [24]. An alternative method uses the bottom-up approach, which collects individual energy efficiency effect on an entity level. Considering that the Latvian energy efficiency policy imposes mandatory energy audits or requires to introduce and maintain a certified energy management system, or supplementary energy management to environmental management system [16], and foresees mandatory reports on identified potential energy efficiency measures (so theoretically there should be enough information on individual energy efficiency measures on an entity level). Authors consider that the more appropriate method of evaluating the energy efficiency potential in industrial sector in Latvia is using bottom-up methodology through widely used energy efficiency cost curves. Andersson et al. (2018) indicate that this method can identify the most cost-effective energy efficiency measures for the industrial sector [25]. This method is lately used in individual NACE divisions such as cement [26], iron and steel, paper and other divisions, as well as in the analysis of individual technologies or systems such as electric motor systems, industrial steam systems [27]. However, the reports submitted by individual entities in Latvia are still being processed and analysed, hence this study will use a top-down approach, comparing the Latvian industry with the EU average, using macroeconomic energy intensity indicators and determining the potential energy efficiency gap and its impact on $\mathrm{CO}_{2}$ emissions.

The EU usually uses energy intensity as indicator to evaluate energy efficiency on a country level [28]. This indicator shows to what extent there is decoupling between energy consumption and economic growth. In environmental context using less energy per unit of economic output equals using energy in a more efficient way; however, the overall climate impacts depend on the total amount of energy consumption, and the fuels and technology used to generate the energy [28]. Energy intensity as energy efficiency indicator is used is national energy efficiency plans, such as NDP [13], and European Directives [3], [4]. 


\section{Materials ANd Methods}

Energy intensity is measured by the amount of energy needed to produce certain economic output of industry [28] and calculated according to Eq. (1):

$$
E I=\frac{E_{\text {ind }}}{G V A_{\text {ind }}},
$$

where

$$
\begin{array}{ll}
E I & \text { energy intensity of certain industrial activity (GJ/EUR, thousands); } \\
E_{\text {ind }} & \text { final energy consumption of certain industrial activity (GJ); } \\
G V A_{\text {ind }} & \text { gross value added at factor costs of certain industrial activity (EUR, } \\
& \text { thousands). }
\end{array}
$$

For the calculation of $\mathrm{CO}_{2}$ emission intensity per certain industrial activity following equation is used:

$$
C I=\frac{E I}{1000} \cdot C F_{\text {ind }},
$$

where

$C I$

$C F_{\text {ind }}$

where

$$
\begin{array}{ll}
C F_{i} & \mathrm{CO}_{2} \text { emissions factor for } i \text { type of fuel }(\mathrm{t} / \mathrm{TJ}) \\
E_{i} & \text { consumption of } i \text { type of fuel }(\mathrm{TJ}) .
\end{array}
$$

$$
C F_{\text {ind }} \frac{\sum_{i}^{n}\left(C F_{i} \cdot E_{i}\right)}{\sum_{i}^{n} E_{i}},
$$

The data about final energy consumption and gross value added at factor costs are taken from Statistical office of the European Union (Eurostat). Gross value added at factor costs is the gross income from operating activities after adjusting for operating subsidies and indirect taxes. It is an indicator (V12150) in the domain of structural business statistics (sbs). SBS cover industry, construction, trade and services, presented according to the NACE activity classification. They describe the structure, conduct and performance of businesses across the EU [29]. Final energy consumption in industry sector (FC_IND_E) is an indicator in domain energy balances that covers all major sectors of the economy that are involved in the production, trade, energy transformation or energy consumption in the EU [30].

For $\mathrm{CO}_{2}$ emissions factors for fuel $\left(C F_{i}\right)$ we used default emission factors for stationary combustion in manufacturing industries and construction from 2006 International Panel of Climate Change Guidelines for National Greenhouse Gas Inventories [31]. $\mathrm{CO}_{2}$ emission intensity for electricity consumption was taken from European Environment Agency [32].

\section{Results AND Discussions}

Latvian energy efficiency gap is calculated using Eq. (1) on macroeconomic level using aggregate country specific statistics. Differences in energy efficiency between industrial sectors 
of Latvia, Estonia, Lithuania, Germany and all EU 28* countries are shown in Fig. 5.

As it is seen from Fig. 5, Latvian industry has the highest energy intensity compared to the peers. The energy efficiency gap or potential saved energy, if the Latvian industry could produce the same amount of value-added product ( 2334 billion EUR of value added) with the average energy intensity in the EU, would be 20578 TJ. Latvian industry consumes approximately 2.6 times more energy to produce same amount of value added. However, in the light of decarbonisation of the EU economies, authors propose to address this issue from the $\mathrm{CO}_{2}$ emissions perspective, whereas in the new energy production conditions of intermitting, undispatchable zero emissions generation, consumers might need to consume additional energy produced from renewable sources, and climate neutral industrial production might become much more important indicator than production efficiency.

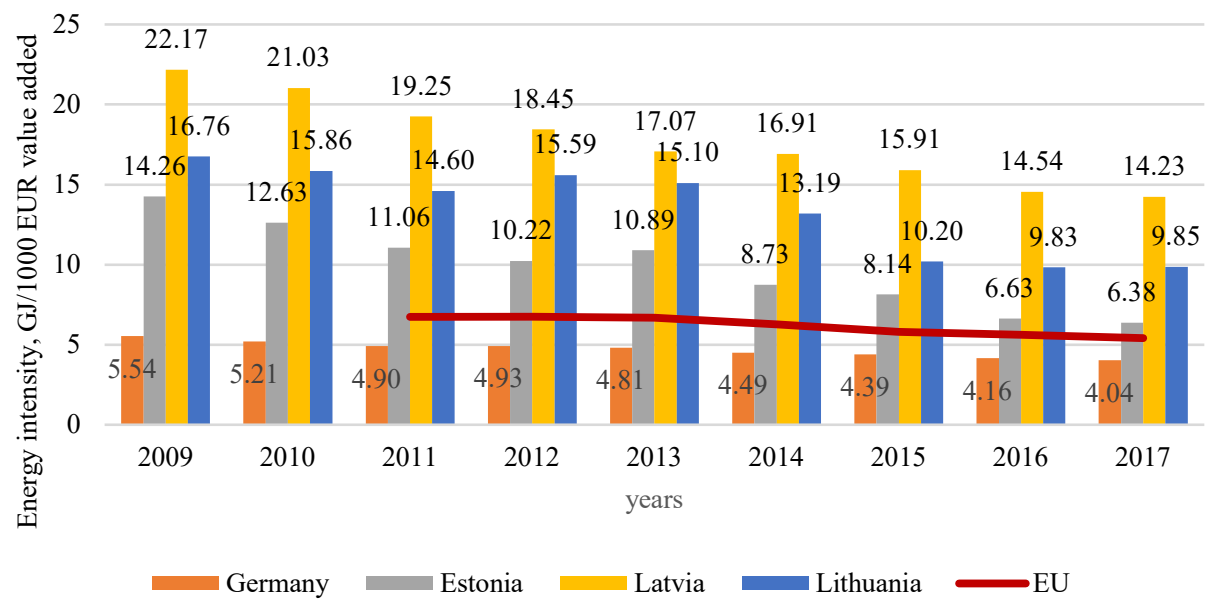

Fig. 5. Industrial energy intensity (created by the authors based on [29], [30]).

Although there is a visible trend of decreasing energy intensity in Latvian industry, this has been achieved mostly by increasing economic activity, while energy consumption trends are still on the rise, although stabilized in recent years. Fig. 6 shows trends in industrial energy consumption, GVA and energy intensity in Estonia, Latvia and Lithuania relatively to 2009 (results are visualised as index points, where $2009=100$ ). Latvia comparing to other Baltic states demonstrates the highest industrial energy intensity index of 64 points (Fig. 6b), whereas Lithuania (Fig. 6c) and Estonia (Fig. 6a) demonstrates 59 and 45 points, respectively.

The top 3 most consuming industries in Latvia, which consumes $89 \%$ of all industrial consumption in Latvia [30], are analysed separately. Manufacture of other non-metallic mineral products (C23) (see Fig. 7), manufacture of food products, beverages and tobacco (C10-12) (see Fig. 8) and manufacture of wood and of wood products (C16) (see Fig. 9). From Figs. 7-9 we can see that all most energy consuming industries in Latvia have relatively high energy intensity compared not only with the EU average, but also with peers in other Baltic states.

‡ Including UK until 2020 


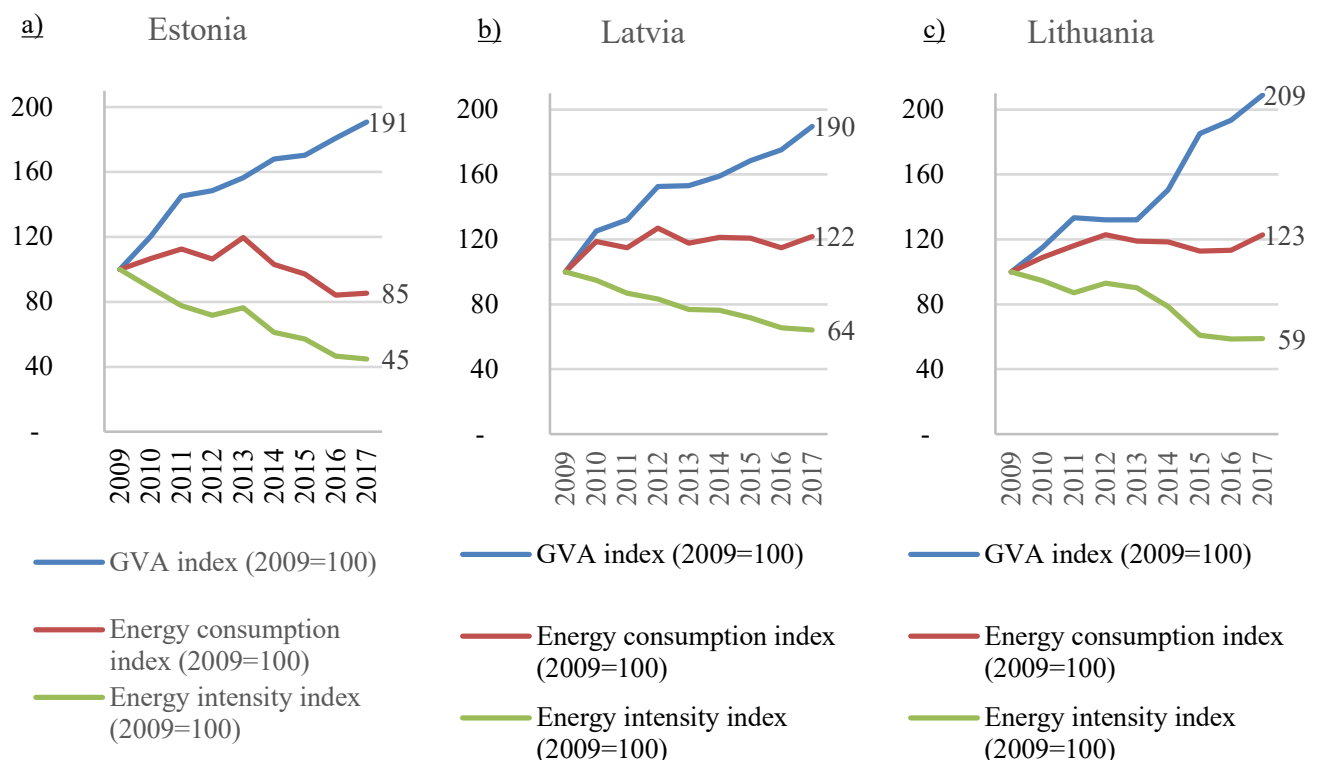

Fig. 6. Trends in industrial energy consumption, GVA and energy intensity a) Estonia; b) Latvia; c) Lithuania (created by the authors based on [29], [30]).

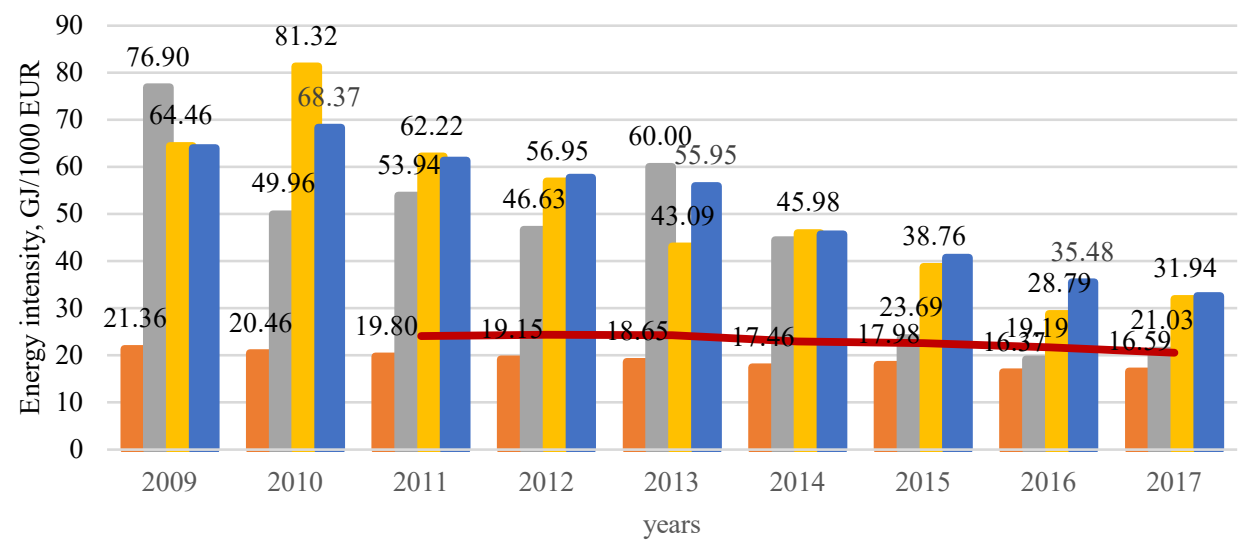

Germany Estonia Latvia Lithuania $\longrightarrow$ EU

Fig. 7. Energy intensity of non-metallic mineral products (C23) (created by the authors based on [29], [30])

Manufacturing of non-metallic minerals in Latvia has the same energy intensity as in Lithuania, however, considerably higher than Estonia, Germany and EU average (see Fig. 8). The energy intensity of this industrial sector has decreased significantly by $60 \%$ from 81.32 GJ/1000 EUR in 2010 to $31.94 \mathrm{GJ} / 1000$ EUR in 2017. 


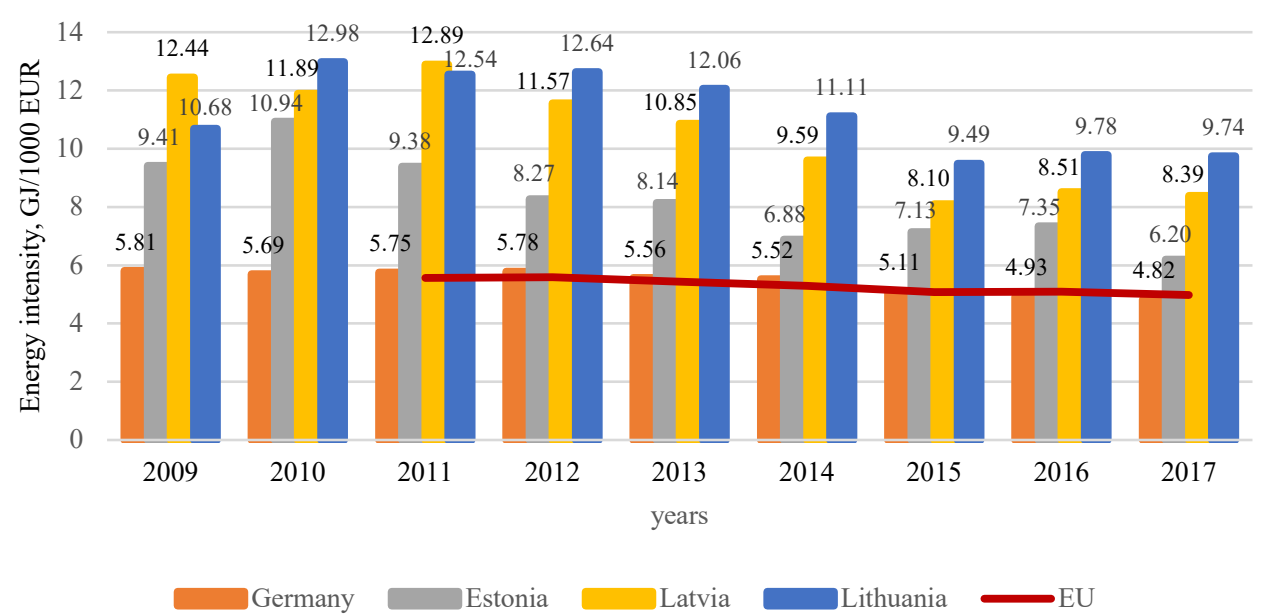

Fig. 8. Energy intensity of food products, beverages and tobacco (C10-12) (created by the authors based on [29], [30]).

Manufacturing of food and beverages in Latvia has lower energy intensity than in Lithuania, however, historically it was other way around (see Fig. 8). The energy intensity of this industrial sector has decreased by $32 \%$ form 12.44 in 2009 to 8.39 in 2017.

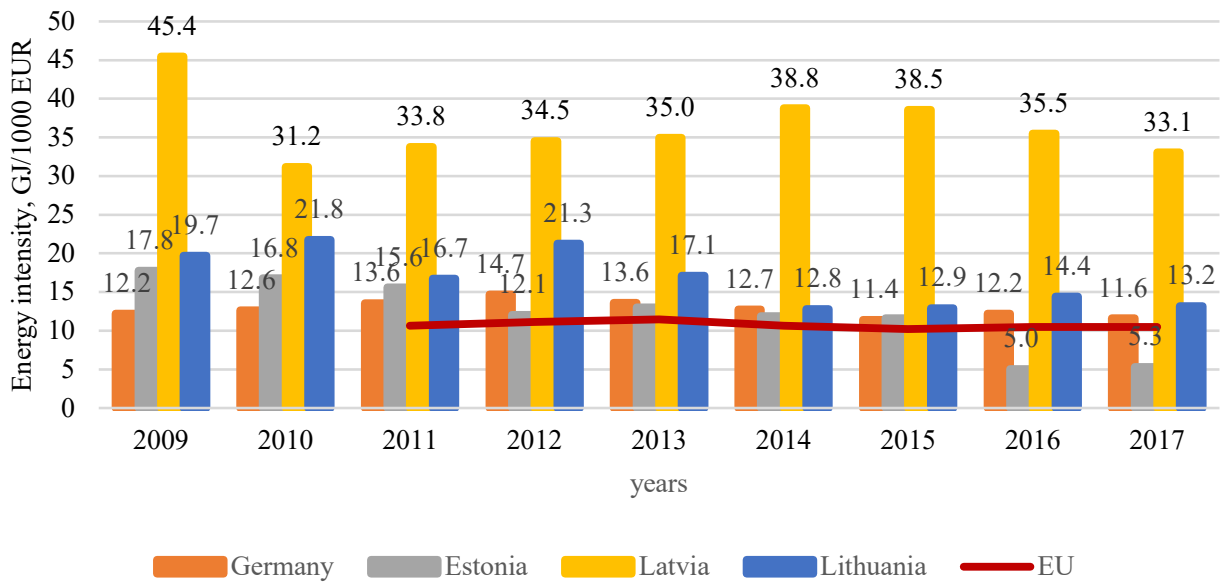

Fig. 9. Energy intensity of wood and wood products (C16) (created by the authors based on [29], [30]).

The most energy consuming industrial sector in Latvia is manufacturing of wood and wood products (C16). It consumes $62 \%$ of all industrial energy consumption in Latvia [30] and demonstrates the significant high energy intensity compared to peers (see Fig. 9). Moreover, unlike other energy consuming industries, it does not show a clear reduction in energy intensity over the years.

In previous publication [33] authors concluded that manufacturing of wood and wood products is significantly affected by certain subsector $\mathrm{C} 1629$, which should be analysed 
separately. European and national statistical offices are not providing energy consumption data of industries on a subsectors level, therefore, in this study, the authors calculated energy consumption of subsector $\mathrm{C} 1629$ using 3-year average energy costs as a proxy. There is no data available of subsector C1629 on the EU level, therefore, Germany's indicator could be used as a benchmark as it is close to the EU average (see Fig. 9).

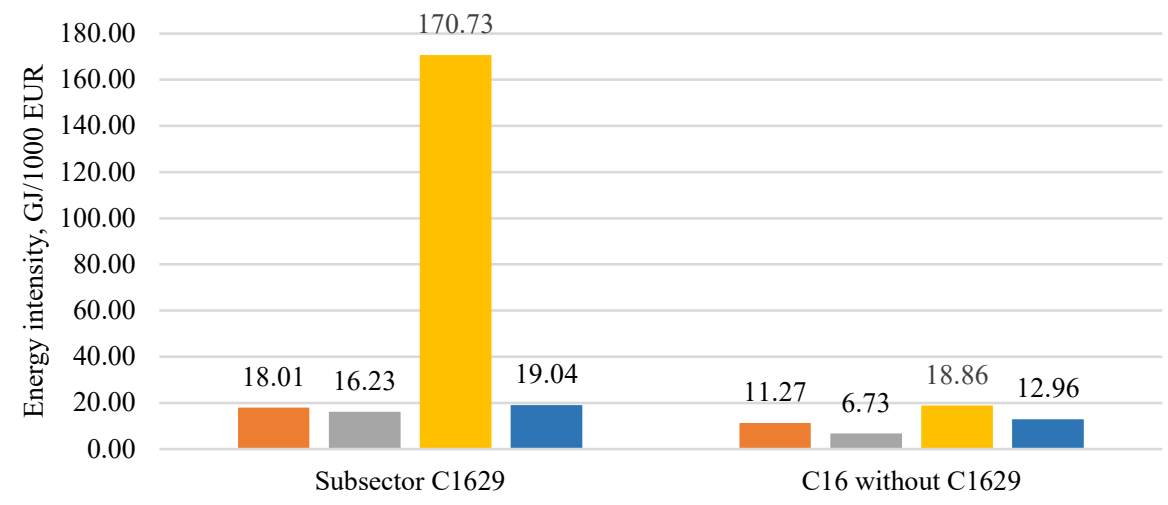

Fig. 10. Energy intensity of single subsector C1629 and wood production (C16) without subsector C1629 (created by the authors based on [29], [30]).

As it is seen from Fig. 10, the wood products subsector C1629, which mostly consist of wood pellets production, is highly energy intensive as it consumes proportionally large amount of energy and produce low added value, however, the results in Fig. 10 should be interpreted considering the limitation of statistical data availability. In addition, it should be noted that manufacturing of wood pellets as well as manufacturing of cement (C23) receive generous energy tax rebates in Latvia [34].

TABLE 3. INDUSTRIAL CONSUMPTION FUEL MIX IN LATVIA AND THE EU AND ITS $\mathrm{CO}_{2}$ EMISSION FACTOR (CREATED By THE AUtHORs BASED ON [30]-32])

\begin{tabular}{lllll}
\hline & $\begin{array}{l}\text { Industrial } \\
\text { consumption } \\
\text { in Latvia, TJ }\end{array}$ & $\begin{array}{l}\mathrm{CO}_{2} \text { emission } \\
\text { factor Latvia, } \\
\text { tonnes/TJ }\end{array}$ & $\begin{array}{l}\text { Industrial } \\
\text { consumption } \\
\text { in EU, TJ }\end{array}$ & $\begin{array}{l}\mathrm{CO}_{2} \text { emission } \\
\text { factor EU, } \\
\text { tonnes/TJ }\end{array}$ \\
\hline Solid fuels & 976 & 95 & 608840 & 95 \\
Oil and petroleum products & 2307 & 73 & 1065461 & 73 \\
Gas & 4505 & 56 & 3715685 & 56 \\
Renewable energies & 14700 & 0 & 956165 & 0 \\
Non-renewable waste & 1093 & 143 & 157537 & 143 \\
Heat & 3291 & 31 & 673162 & 50 \\
Electricity & 6347 & 29 & 3763146 & 82 \\
\hline Weighted average emission factor & & 29 & & 65 \\
\hline
\end{tabular}

To compare Latvian and the EU industrial $\mathrm{CO}_{2}$ emissions, first we studied the energy mix of Latvian and the EU industry. The results are shown in Fig. 11. The emission factor of industry's fuel mix is calculated using Eq. (3) and is shown in Table 3. 
a)

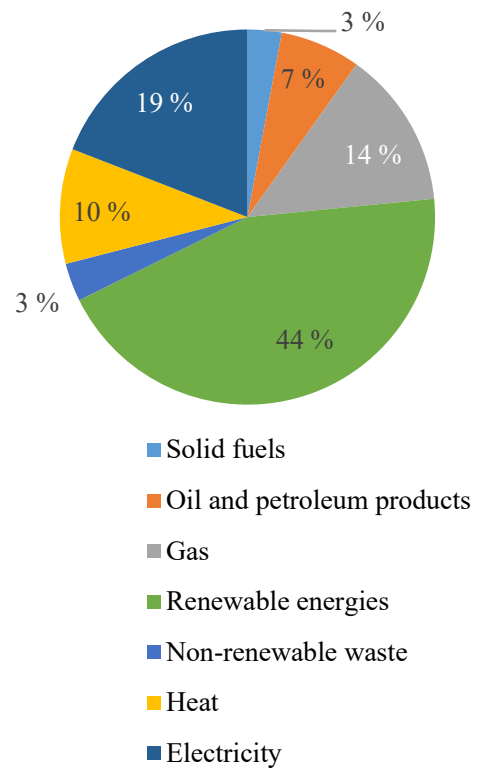

b)

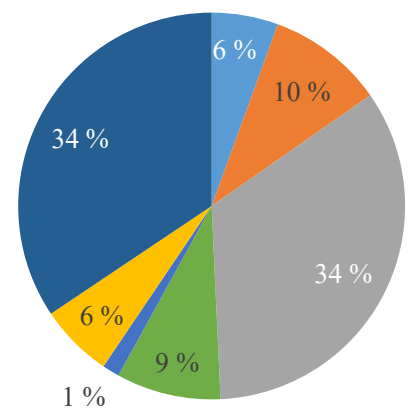

- Solid fuels

$\square$ Oil and petroleum products

$\square$ Gas

- Renewable energies

- Non-renewable waste

Heat

- Electricity

Fig. 11. Industry fuel mix (2017): a) Latvia; b) EU (created by the authors based on [30]).

Considering the different industrial intensities in the EU and Latvia and the weighted average emission factor of different industrial fuel mix, it can be calculated using Eq. (2) that production of industrial gross value added of EUR 1000 emits $352.3 \mathrm{~kg}$ of $\mathrm{CO}_{2}$ on average in the EU and $412.7 \mathrm{~kg}$ of $\mathrm{CO}_{2}$ in Latvia. A weighted average emission factor of $24 \mathrm{t} / \mathrm{TJ}$ in Latvian industry's fuel mix would eliminate the $\mathrm{CO}_{2}$ emissions gap between Latvian and EU industries, however, the energy efficiency gap compared to the EU average would still remain (see Fig. 12).
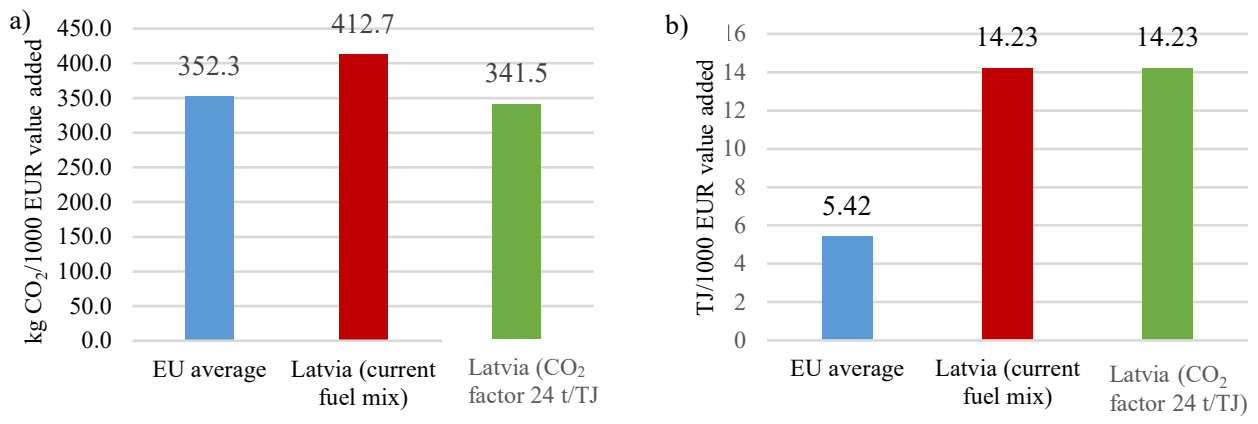

Fig. 12. Industrial (a) $\mathrm{CO}_{2}$ emissions and (b) energy consumption to produce EUR 1000 of gross value added (2017) in EU average and Latvia with current energy mix and with reduced emission factor (created by the authors).

To evaluate the ambition level of Latvian industrial energy efficiency goals for the next decade, authors supplemented the actual Latvian industrial energy intensity curve with targeted intensity in 2020 (from NDP) and 2030 (from NECP) (see Fig. 13), and concluded that the actual reference points and new targets have good correlation and the curve has 
exponential form with $R^{2}=0.9962$ (see Fig. 13). This leads to a conclusion that for the industrial sector the expected energy efficiency targets for 2030 will follow to the path already taken, and it is expected that industry should contribute more to close the existing efficiency gap towards Green Deal transition (see Fig. 13).

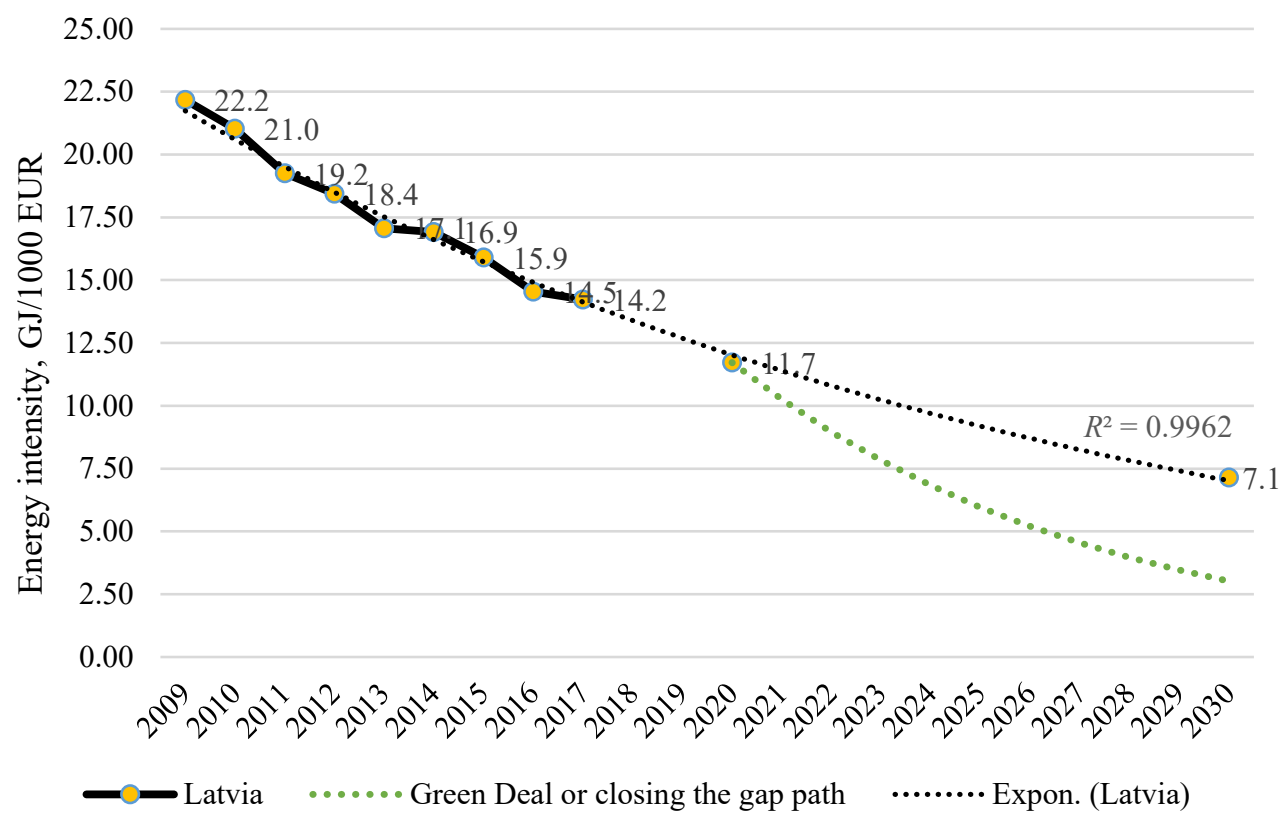

Fig. 13. Historical industrial energy intensity and targets for 2020 and 2030 shows significant correlation, but lacks the Green Deal perspective (created by the authors based on [5], [13, [18].

To evaluate the industrial $\mathrm{CO}_{2}$ emissions to produce EUR 1000 of gross value added, the energy mix in 2030 and weighted average emission factor was recalculated, taking into account further assumptions from NECP: the share of renewable electricity production $70 \%$, remaining $30 \%$ from gas cogeneration power plants, share of renewables in heat $60 \%$. All other non-renewable resources are substituted with fuel equivalent of natural gas in terms of $\mathrm{CO}_{2}$ emission factor. Considering these assumptions, the average weighted $\mathrm{CO}_{2}$ emission factor for industrial fuel mix would be $21 \mathrm{t} / \mathrm{TJ}$. Results show that to produce EUR 1000 of gross value added in industry in 2030 , it would need to emit $142 \mathrm{~kg}$ of $\mathrm{CO}_{2}\left(412.7 \mathrm{~kg}\right.$ of $\mathrm{CO}_{2}$ in 2017). And further decarbonisation of the industry is possible by radically changing the fuel mix.

\section{Conclusions}

In this research we used a top-down approach to evaluate industrial energy efficiency potential in Latvia, using macroeconomic indicators. The research confirmed that on a macro level Latvian industry has higher energy intensity compared to the EU average levels as well as peers from Germany, Estonia and Lithuania. Although there is a visible trend of decreasing energy intensity in Latvian industry, national energy efficiency plans show that energy intensity will remain relatively high in the next decade, not even reaching today's EU average. 
Target levels of industrial energy efficiency by 2030 lack ambitions. Although the applied top-down method has several known drawbacks as it does not consider the structural differences of industries and prices of different industrial products, the research confirms that Latvian industry consumes on average 2.6 times more resources to produce the same value of industrial production compared to the EU average and emits $60 \mathrm{~kg}$ of $\mathrm{CO}_{2}$ more per EUR 1000 of production value added. Which means that the industry in Latvia has a very high untapped energy efficiency potential, although the increase in energy efficiency will have a relatively small impact on $\mathrm{CO}_{2}$ reduction due to the twice lower $\mathrm{CO}_{2}$ intensity of the Latvian industry's energy mix compared to the EU average. That also leads to the conclusion that $\mathrm{CO}_{2}$ pricing as one of the tools to incentivize industrial energy efficiency will have twice lower effect in Latvia compared to the EU.

In the spotlight of the Green Deal proposal much higher contribution in terms of $\mathrm{CO}_{2}$ reduction and energy efficiency will be expected from the industry. However, the specific Latvian case, where industrial energy mix is already largely decarbonized due to a high share of wood and wood products production, proves that setting energy efficiency targets should be sector-specific, separately addressing $\mathrm{CO}_{2}$ intensive sectors (such as the production of cement), and $\mathrm{CO}_{2}$ non-intensive industrial sectors with low added value (such as the production of wood pellets). The energy efficiency of $\mathrm{CO}_{2}$ intensive sectors could be addressed with existing policy tools such as EU Emissions Trading System, while insuring against the 'carbon leakage' across EU borders. While low $\mathrm{CO}_{2}$ intensity sectors should be evaluated in terms of value added, noting that there might be very limited cost-effective carbon-free energy efficiency measures, however, subsidizing these sectors should be eliminated, as it dis-incentivize the energy efficiency measures.

\section{ACKNOWLEDGEMENT}

This research is funded by the Ministry of Economics of the Republic of Latvia, project "Energy and climate modelling towards net zero emissions", project No. VPP-EM-2018/NEKP-0001.

\section{REFERENCES}

[1] Council Directive 93/76/EEC of 13 September 1993 to limit carbon dioxide emissions by improving energy efficiency (SAVE). Official Journal of European Union 1993: L 237.

[2] Directive 2006/32/EC of the European Parliament and the Council of 5 April 2006 on energy end-use efficiency and energy services and repealing Council Directive 93/76/EEC. Official Journal of European Union 2006: L 114.

[3] Directive 2012/27/EU of the European Parliament and of the Council of 25 October 2012 on energy efficiency, amending Directives 2009/125/EC and 2010/30/EU and repealing Directives 2004/8/EC and 2006/32/EC. Official Journal of European Union 2012: L 315.

[4] Directive 2012/27/EU of the European Parliament and of the Council of 11 December 2018-2020 on energy efficiency. Official Journal of European Union 2018: L 328.

[5] European Commission. The European Green Deal. 2019. 640 final.

[6] European Union, Directorate-General for Energy (2019). Clean energy for all Europeans. [Online]. [Accessed 29.01.2020]. Available: https://op.europa.eu/en/publication-detail/-/publication/b4e46873-7528-11e9-9f0501 aa75ed71a1

[7] European Union, Energy Commissioner Aria Canete (2015) Speech by Commissioner Arias Cañete at the Lisbon Council. Towards an Effective Energy Union. [Online]. [Accessed 30.01.2020]. Available: https://ec.europa.eu/commission/presscorner/detail/en/SPEECH_15_4439

[8] Communication from the Commission - Guidelines on State aid for environmental protection and energy 2014-2020, Official Journal of the European Union 2014: L 57.

[9] Locmelis K., Blumberga A., Bariss U., Blumberga D. Energy policy for energy intensive manufacturing companies and its impact on energy efficiency improvements. System dynamics approach. Energy Procedia 2017:128:10-16. https://doi.org/10.1016/j.egypro.2017.09.005 
[10] Directive 2003/87/EC of the European Parliament and of the Council of 13 October 2003 establishing a system for greenhouse gas emission allowance trading within the Union and amending Council Directive 96/61/EC. OJ L 275 25.10.2003.

[11] Cabinet of Ministers of Latvia. First Energy Efficiency Action Plan of the Republic of Latvia 2008-2010. Latvijas Vēstnesis, Issue 79, 22.05.2008.

[12] Cabinet of Ministers of Latvia. Second Energy Efficiency Action Plan of the Republic of Latvia 2011-2013. Latvijas Vēstnesis, Issue 148, 20.09.2011.

[13] National Development Plan of Latvia for 2014-2020. Latvijas Vēstnesis, Issue 6, 09.01.2013.

[14] Ministry of Economics of Latvia. On the progress towards the indicative national energy efficiency targets in $2014-$ 2016 according to Directive 2012/27/EU of the European Parliament and of the Council of 25 October 2012 on energy efficiency, amending Directives 2009/125/EC and 2010/30/EU and repealing Directives 2004/8/EC and 2006/32/EC, $\begin{array}{llll}2014 . & \text { [Online]. 30.01.2020]. Available: }\end{array}$ https://ec.europa.eu/energy/sites/ener/files/documents/neeap_2014.zip

[15] Energy Efficiency Law. Latvijas Vēstnesis, Issue 52, 2016. [Online]. [Accessed 29.01.2020]. Available: https://likumi.lv/ta/en/en/id/280932-energy-efficiency-law [29.01.2020]

[16] Locmelis K., Blumberga D., Bariss U. Energy efficiency in large industrial plants. Legislative aspects. Energy Procedia 2018:147:202-206. https://doi.org/10.1016/j.egypro.2018.07.058

[17] Cabinet of Ministers of Latvia. Alternative measure plan of Latvian energy efficiency policy on achieving final consumption energy efficiency targets for the period 2014-2020 from 24 May 2017. Latvijas Vēstnesis, Issue 104, 29.05.2017. [Online]. [Accessed 31.01.2020]. Available: https://www.vestnesis.lv/op/2017/104.8

[18] Cabinet of Ministers of Latvia. National energy and climate plan 2021-2030. [Online]. [Accessed 31.01.2020]. Available: https://em.gov.lv/lv/nozares_politika/nacionalais_energetikas_un_klimata_plans/

[19] Knoop K., Lechtenböhmer S. The potential for energy efficiency in the EU Member States - A comparison of studies. Renewable and Sustainable Energy Reviews 2017:68(P2):1097-1105. https://doi.org/10.1016/j.rser.2016.05.090

[20] Jaffe A., Stavins R. The energy-efficient gap: What does it mean? Energy Policy 1994:22(10):804-810. https://doi.org/10.1016/0301-4215(94)90138-4

[21] Mosenthal P., Loiter J. Guide for Conducting Energy Efficiency Potential Studies. National Action Plan for Energy Efficiency, 2007.

[22] Boyd G., McDonald J. F., Ross M., Hansont D. A. Separating the Changing Composition of U.S. Manufacturing Production from Energy Efficiency Improvements: A Divisia Index Approach. The Energy Journal, International Association for Energy Economics 1987:2:77-96. https://doi.org/10.5547/ISSN0195-6574-EJ-Vol8-No2-6

[23] Jenne C. A., Cattell R. K. Structural change and energy efficiency in industry. Energy Economics 1983:5(2):114-123. https://doi.org/10.1016/0140-9883(83)90018-X

[24] Howarth R. B., Schipper L., Duerr P. A., Strøm S. Manufacturing energy use in eight OECD countries: Decomposing the impacts of changes in output, industry structure and energy intensity. Energy Economics 1991:13(2):135-142. https://doi.org/10.1016/0140-9883(91)90046-3

[25] Andersson E., Karlsson M., Thollander P., Paramonova S. Energy end-use and efficiency potentials among Swedish industrial small and medium-sized enterprises - A dataset analysis from the national energy audit program. Renewable and Sustainable Energy Reviews 2018:93:165-177. https://doi.org/10.1016/j.rser.2018.05.037

[26] Zuberi M. J. S., Patel M. K. Bottom-up analysis of energy efficiency improvement and $\mathrm{CO}_{2}$ emission reduction potentials in the Swiss cement industry. Journal of Cleaner Production 2017:142(P4):4294-4309. https://doi.org/10.1016/j.jclepro.2016.11.178

[27] Hasanbeigi A., Harrell G., Schreck B., Monga P. Moving beyond equipment and to systems optimization: Techno-economic analysis of energy efficiency potentials in industrial steam systems in China. Journal of Cleaner Production 2016:120:53-63. https://doi.org/10.1016/j.jclepro.2016.02.023

[28] European Environmental Agency. Indicators. Intensity of final energy consumption in Europe. 2019. [Online]. [Accessed 31.03.2020]. Available: https://www.eea.europa.eu/data-and-maps/indicators/final-energy-consumptionintensity-5

[29] Statistical office of the European Union. Annual detailed enterprise statistics for industry. Value added at factor cost (V12150). 2019. [Online]. [Accessed 31.01.2020]. Available: https://ec.europa.eu/eurostat/data/database

[30] Statistical office of the European Union (2020). Simplified energy balances. Final consumption - industry sector energy use (FC_IND_E). [Online]. [Accessed 31.01.2020]. Available: https://ec.europa.eu/eurostat/data/database

[31] The Intergovernmental Panel on Climate Change. IPCC Guidelines for National Greenhouse Gas Inventories. 2006. [Online]. [Accessed 31.01.2020]. Available: https://www.ipcc-nggip.iges.or.jp/public/2006gl/vol2.html

[32] European Environmental Agency. $\mathrm{CO}_{2}$ emission intensity. [Online]. [Accessed 31.01.2020]. Available: https://www.eea.europa.eu/data-and-maps/daviz/co2-emission-intensity-5

[33] Locmelis K., Bariss U., Blumberga D. Energy Efficiency Obligations and Subsidies to Energy Intensive Industries in Latvia. Environmental and Climate Technologies 2019:23(2):90-101. https://doi.org/10.2478/rtuect-2019-0057

[34] Locmelis K., Blumberga D. Energy taxation exemptions for energy intensive industries and its impact on energy efficiency in Latvia. 2019 IEEE $60^{\text {th }}$ International Scientific Conference on Power and Electrical Engineering of Riga Technical University (RTUCON). Riga, Latvia, 2019. https://doi.org/10.1109/RTUCON48111.2019.8982313 